\title{
PROBLEMS OF TREE AND SHRUB FELLING LESSON FROM POLAND
}

\author{
Grazyna Gawronska, Krzysztof Gawronski, Karol Krol \\ University of Agriculture in Krakow, Poland \\ g.gawronska@urk.edu.pl,k.gawronski@ur.krakow.pl,k.krol@onet.com.pl
}

\begin{abstract}
Greenery is an inherent component of both natural and anthropogenic environments. Green areas fulfil three basic functions: economic, environmental and social. They build the city landscape and influence its urban composition. One of the most important environmental problems is felling of trees and shrubs. Excessive felling may cause disturbance of biodiversity and ecosystems. This paper attempts to analyse the process of cutting down trees and shrubs in Poland on the example of Przeworsk Commune (Podkarpackie Province). Descriptive and analytical methods were employed. The principles of cutting down trees and shrubs in Poland were presented in compliance with applicable legal regulations. The economic effects of felling of trees and shrubs were described. The analysis of the process of felling of trees and shrubs was carried out on the basis of data obtained from the City Hall of Przeworsk. The years 2013-2017 were analysed. In Przeworsk commune, in 2013-2017, fees for removing trees from legal persons were charged. However, in 2015 the charged fees were cancelled. At the same time, it has been noted that the legal changes in Poland that occurred in 2017 caused a significant violation of the environment due to uncontrolled felling of trees and shrubs. It has been shown that shrub planting can compensate for the loss of greenery (ad hoc plantings), and of trees in particular.
\end{abstract}

Keywords: trees, shrubs, economic effects, loss of greenery, ad hoc plantings

\section{Introduction}

Natural environment is the entirety of natural components including those transformed by humans, in particular the Earth's surface, waters, the air, minerals, climate, landscape, and other biological resources as well as interactions between these components. Environmental protection involves in particular reasonable shaping of the environment and management of its resources in line with the principle of sustainable development, pollution prevention, and restoration of natural components to their previous state. On the other hand, nature preservation is defined as a system of social, state, administrative, economic, and legal activities aimed at the conservation of resources that are beneficial for life [1-3]. Nature preservation involves preservation, sustainable use, and renewal of natural resources, formations, and components as well as the landscape [4]. Environmental components are exploited, subjected to pressure, and developed, usually within the limits of the legal norms in force [5].

Greenery is an inherent component of the natural environment, including the urbanised space. Green areas are landscaped grounds which, along with technical infrastructure and buildings, are covered with vegetation and maintain public functions. Green areas provide ecosystem services including provisioning, regulating, and cultural ones. As a green infrastructure component, they serve three basic functions: economic, environmental, and social [6]. The roles of green areas include, e.g. the creation of the functional structure of towns and cities, and the development of landscape and urban composition of urban and rural spaces. Trees and shrubs are a significant component of green areas.

A tree is a perennial plant with a single woody main trunk or a few main stems and branches that form the tree-crown. Trees are important components of the space, and have a significant effect on the microclimate [7;8]. They purify the air and lower its temperature, and create a protective barrier against solar radiation and gusts of wind [9]. On the other hand, shrubs are perennial plants, which branch into many stems or trunks at the base but have no crown. Trees and other plants are components of the ground from the time they were planted [10].

Over the last several years, striving for improving the quality of the environment and its components could be observed. This is hindered, e.g. by the processes of progressive urbanisation as well as infrastructure and socio-economic development, which often lead to the loss of biologically active areas and agricultural and forestry land [11]. Green areas located within both city centres and suburban areas often become the subject area of a targeted investors' policy aimed at developing the available space, the designation of which has not been specified in the local area development plan [12]. In recent years, one of the major environmental problems in Poland has been felling of trees and shrubs. In many cases, this felling has adversely affected the biodiversity of ecosystems. The rate of tree and shrub felling increased significantly in Poland in 2017, which was a consequence of the 
adopted regulations. This problem has equally affected urban and rural areas. The purpose of the paper is to analyse the process of tree and shrub felling in Poland, its course, and economic and environmental consequences. The following research question was raised: to what extent have the amendments to regulations affected the rate of tree and shrub felling in Poland?

\section{Materials and methods}

The study applied the descriptive and analytical method. The process of tree and shrub felling in Przeworsk commune in the years 2013-2017 was analysed. The analysed period was divided into three main periods during which significant amendments were introduced to the regulations governing the tree and shrub felling process: (1) the first period running from 1 January 2013 to 31 December 2016; (2) the second period running from 1 January to 17 June 2017; and (3) the third period running from 17 June to 31 December 2017. Subsequently, a quantitative analysis of the rate of tree and shrub felling in each of the indicated periods was conducted in order to observe relationships between the legislation in force and the felling rate.

The town of Przeworsk is located in the south-eastern part of Poland, in Podkarpackie Province (Fig. 1). Przeworsk along with 8 communes, namely Przeworsk, Kańczuga, Sieniawa, Adamówka, Gać, Tryńcza, Zarzecze and Jawornik Polski, make up Przeworski Poviat.

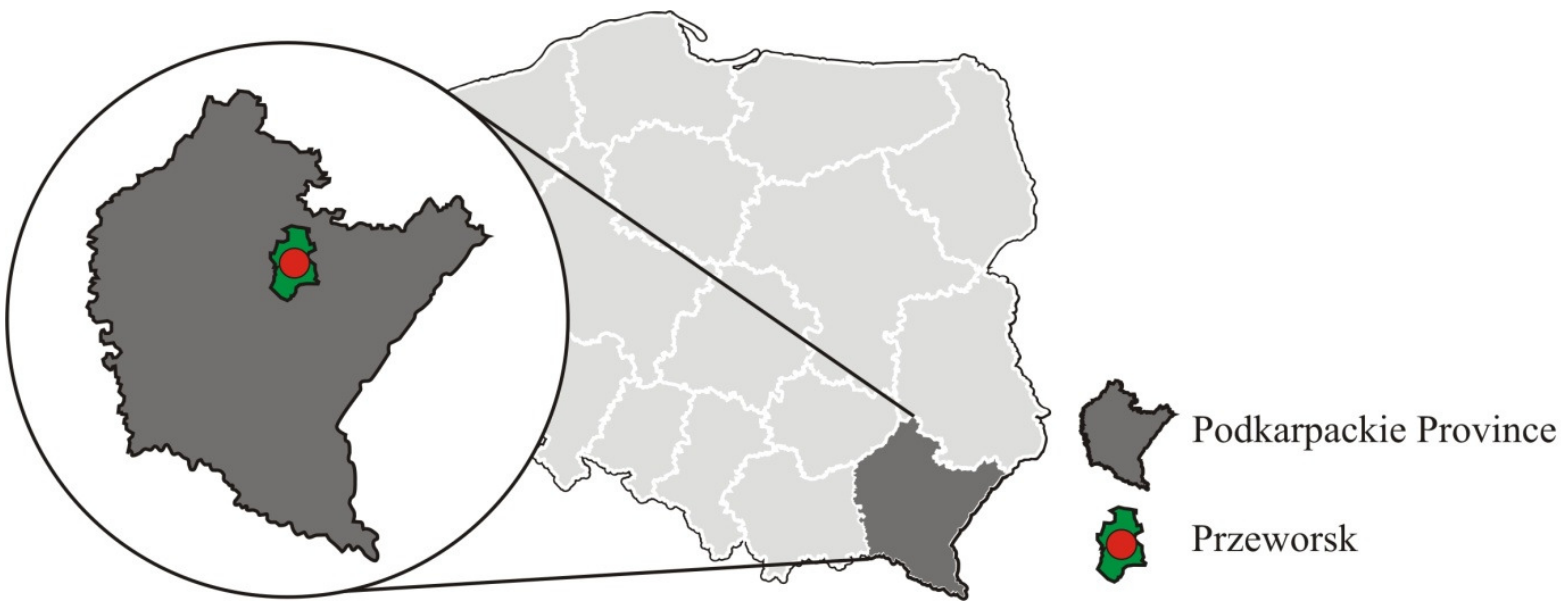

Fig. 1. Location of Przeworsk Commune on map of Poland (illustrative image)

Przeworsk covers an area of $22 \mathrm{~km}^{2}$ and is located in the Vistula River basin, in the ForeCarpathian Depression, between the Rzeszów Foreland and the Dynowskie Foothills. The topography of the commune fosters investments including the extension of the range of single- and multi-family houses, with the exception of landslide areas and land in close vicinity of the Mleczka River.

In Poland, the Act on Nature Conservation is one of the fundamental legislative acts aimed at the conservation of natural assets [13]. This conservation is also governed by the Regulations of the Council of Ministers, Regulations of the Minister of the Environment, and other legislative acts issued by commune heads or mayors. These norms have an effect on the environmental management and conservation policy, including the tree and shrub felling.

Rules concerning tree and shrub felling, valid from 1 January 2013 to 31 December 2016

The administrative law system in Poland defines instruments aimed at conservation of trees and shrubs, of which the main one is a permit for felling. In Poland, a permit for removal of trees and shrubs was in force until 31 December 2016, and was issued by commune heads or mayors at the request of: (1) the land possessor - with the consent of the owner of the land, and (2) the facility owner, where a tree or shrub posed a hazard to this facility [10].

One of the key principles in tree and shrub felling was that the fees for their removal were to be borne by the owner of the land. The fees were specified in the permit and charged based on the rate depending on the circumference of the trunk measured at a height of $130 \mathrm{~cm}$, on the trunk growth rate, and on the coefficients differentiating the rates depending on the location of the tree. The fees charged for shrubs were calculated as the number of square meters $\left(\mathrm{m}^{2}\right)$ of the area covered with shrubs and multiplied by the coefficient differentiating the rate depending on the location of the shrub. In the 
situation, where the fee for tree or shrub felling was charged, and the issue of the permit for a tree or shrub felling was made dependent on either replanting or ad hoc planting, a public administration body could defer the payment of the fee for a period of 3 years. The rates of the fees and the coefficient values were specified in the Regulation of the Minister in charge of the environment.

Rules concerning tree and shrub felling, valid from 1 January to 17 June 2017

On 16 December 2016, the Act on the amendment to the Act of 16 April 2004 on nature conservation (consolidated text: Journal of Laws of 23 December 2016, item 2134) was passed. The Act entered into force on 1 January 2017 (Journal of Laws of 2016, item 2249), and was effective until 17 June 2017. The revision extended the scope of tree and shrub felling without permission. Permit was not required for: (1) trees and shrubs which were located on properties owned by natural persons, and were felled for purposes unrelated to business activity, and (2) trees and shrubs removed in order to restore land to agricultural use. It followed from revision of the regulations that: (1) the person who was the land owner could remove a tree or shrub, regardless of its size or species, if this was not related to conducting a business activity, and (2) a farmer could fell a tree or shrub without permission in order to resume the cultivation. The amendments, which entered into force on 1 January 2017, primarily facilitated the process of tree and shrub felling to natural persons, who did not conduct business activity. Moreover, the commune head or mayor were granted extensive powers to introduce amendments concerning the tree and shrub felling by way of local legislative act, e.g. determination of fee rates [14].

\section{Rules concerning tree and shrub felling, valid from 17 June to 31 December 2017}

The second significant revision of the Act on Nature Conservation [13] entered into force on 17 June 2017. The legislator restored, in many issues, the regulations in force in 2016. In addition, restrictions on free felling of trees and shrubs were restored. From 17 June 2017, a tree or shrub could be removed after obtaining the permit. In this way, the legislator introduced a ban of felling which could be repealed only in selected cases. The fees related to tree and shrub felling were charged in the permit issued by the relevant public administration body. Payment of the fee was deferred for a period of 3 years, and made dependent on ad hoc plantings or replantings. The fee was remitted, if the tree or shrub has maintained its vitality after 3 years. Moreover, the legislator returned to the practice of determining the fee rates in the Regulation issued by the Minister in charge of the environment.

\section{Results and discussion}

During the analysed period, the predominance of applications for the permit for tree and shrub felling submitted by natural persons was noted. In the years 2013-2016, the number of submitted applications remained at a similar level each year, while during the period from 1 January to 17 June 2017, the number of submitted applications decreased significantly. At this point, it should be reminded that from 1 January to 17 June 2017 there was a possibility for felling a tree or shrub without permission by a natural person conducting no business activity.

The greatest number of applications for the permit for tree and shrub felling were noted in 2014, and the smallest number of applications in 2017 (Fig. 2). In the years 2013-2016, a slight increase in the number of applications for the permit for tree and shrub felling submitted by legal persons could be noted. On the other hand, their reduction was noted in the following year. During the period from 1 January to 17 June 2017, decisions permitting tree and shrub felling in Przeworsk were primarily issued to economic operators.

Figure 3 shows the number of trees and shrubs whose felling was recorded in Przeworsk commune in the years 2013-2017. Most fellings were recorded in 2014 and 2016, and the least in 2017. This was due to revision of the regulations, which introduced the freedom to remover trees and shrubs on land owned by a natural person. The tree and shrub felling which took place during that period was not fully documented. During the analysed period, shrubs were removed occasionally (Fig. 3).

The Act on Nature Conservation [13] makes the issue of the permit for tree and shrub felling dependent on carrying out ad hoc plantings or replanting a particular tree or shrub. During the analysed period, ad hoc shrub plantings were carried out more often than ad hoc tree plantings (Fig. 4). The greatest number of plantings (216 trees and 2016 shrubs) was noted in 2014. In the following years, a smaller number of plantings was noted, with the lowest one in 2017. 


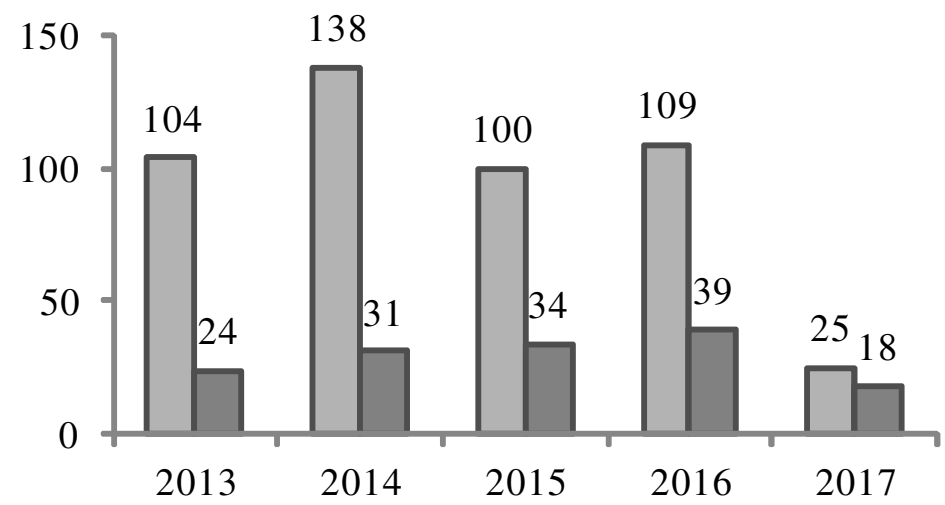

$\square$ Number of applications submitted by natural persons

$\square$ Number of applications submitted by legal persons

Fig. 2. Comparison of number of applications submitted for permit for tree and shrub felling by natural and legal persons in Przeworsk in 2013-2017

Source: own study based on data provided by Przeworsk Town Council

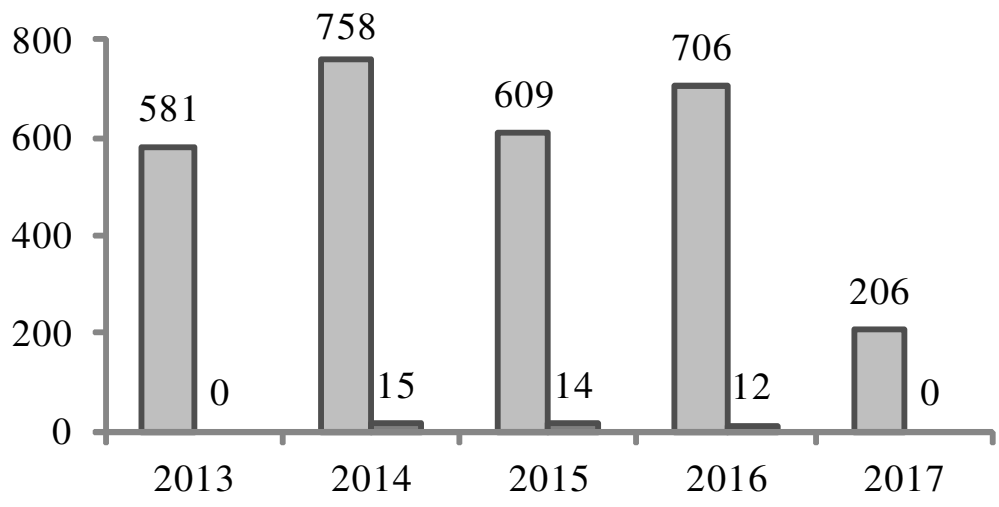

$\square$ Number of trees felled

Number of shrubs felled

Fig. 3. Number of trees and shrubs felled in Przeworsk in 2013-2017

Source: own study based on data provided by Przeworsk Town Council

In the years 2013-2017, public administration bodies in Przeworsk commune issued a decision rejecting the request for felling of 21 trees including: in 2013 - for 3 trees (silver birch, field elm, sycamore, mountain-ash); in 2014 - no decisions rejecting the request for felling; in 2015 - for European ash and sycamore; in 2016 - for 10 trees ( 2 blue spruces, 6 Canadian poplars, 1 field elm, and 1 silver birch); in 2017 - for 5 black locusts and 1 European larch.

In Przeworsk, in the years 2013-2017, fees were charged for removal of trees and shrubs from legal persons in the amount of PLN 331072.93 (approx. 77500 EUR; the average Euro exchange rate was PLN 4.274 as at 31 January 2019). These fees were remitted for a period of 3 years for ad hoc plantings. In 2015, they were remitted on condition that 10 Cornelian cherry trees shall be planted; in 2017 , on condition that 285 ornamental shrubs shall be planted. No funds from tree and shrub felling were therefore transferred to the commune budget.

The research conducted on a group of 34 cities showed that a law concerning tree protection seems to make sense, if it can be implemented in a non-bureaucratic and efficient way, respecting protection and conservation of nature. Out of the 34 cities, which were contacted or for which legal documents were found on the Internet, 25 (74\%) had laws protecting trees in public and/or private areas. In all 25 cities felling of protected trees depended on official authorisation. In many laws interdictions concerning trees were listed. Most frequently, it was prohibited to cut down, to remove, to fell, to damage, to destroy, to modify, and to prune protected trees, and to enhance their decay [15].

Although there are many publications concerning flora in certain cities in Poland, tree inventories have not been conducted for spatial planning purposes. As a result, detailed data on tree numbers and their distribution, which could be used in decision making and urban ecosystem management processes, are lacking. It is unknown how many trees grow in Polish urban areas, precisely where they 
grow and what specific changes have occurred in urban tree cover. However, it is known that the number of trees in central areas of Polish towns (with a few exceptions) has been decreasing [16].

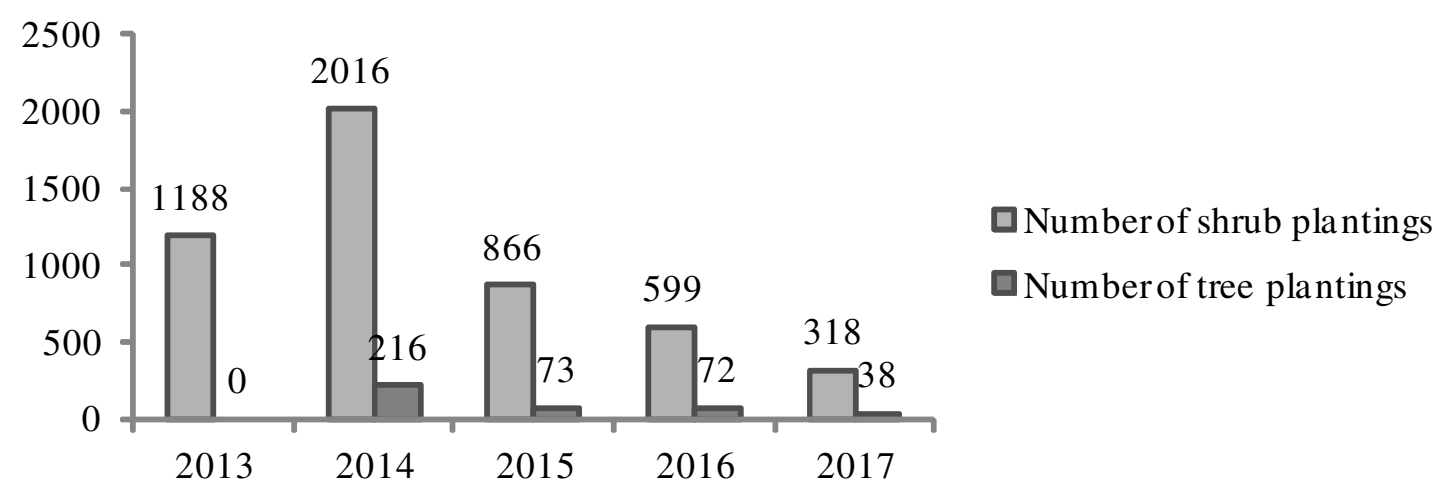

Fig. 4. Number of tree and shrub plantings in Przeworsk in 2013-2017

Source: own study based on data provided by Przeworsk Town Council

Regulations concerning tree and shrub felling in Poland were changing significantly in the years 2016-2017. By the end of 2016, in order to be able to fell a tree or shrub, it was necessary to apply to the relevant public administration body for the issue of the permit for felling. The Act, which entered into force on 1 January 2017, liberalised the previous regulations. The lack of requirement to obtain the permit for felling a tree or shrub by natural persons for purposes unrelated to conducting economic activity has led to both positive and negative consequences. The revision of regulations facilitated the tree and shrub felling to natural persons who were owners of land. Moreover, it reduced the number of related administrative actions. By way of revision of the law, fines for removal of a tree or shrub without permission were reduced as well. The disadvantages of this particular legislation in force were the excessive freedom to fell trees and shrubs. Revision of the regulations resulted in the loss of administrative control over felling, which led to the loss of environmental resources and, in many cases, naturally valuable species. There were also situations where the ownership of land was transferred to a natural person for them to carry out the felling, after which the land with removed trees was transferred back to the entity conducting economic activity.

New regulations granted Commune Councils a wide range of powers. The Commune Council was entitled to decide, by means of local legislative act, on the rules concerning tree and shrub felling. After the new regulations, which became effective on 1 January 2017 had been in force for half a year, new amendments were introduced, which were effective from 17 June 2017. The obligation to report tree and shrub felling was reinstated. The Commune Council lost the powers previously granted to it.

\section{Summary and conclusions}

In reports on tree stand felled in Przeworsk in the years 2013-2017, deciduous trees and coniferous shrubs were predominant. The main species of trees that were removed included: Norway spruce, silver birch, poplar, and black locust. In the ad hoc plantings intended to compensate for vegetation losses in the commune area, shrubs were dominant.

In the course of the study, a number of relationships between the regulations in force during the particular period and the rate of tree and shrub felling were noted. In Przeworsk commune, in the years 2013-2016, from approx. 600 to approx. 800 trees and, on average, approx. 12 shrubs were felled per year. Due to the revision of the law, which was effective from 1 January 2017, it is not possible to determine precisely the number of trees and shrubs removed during the period from 1 January to 17 June 2017. Moreover, revision of the law resulted in significant violation of environmental assets due to uncontrolled felling of trees and shrubs. The subsequent revision of the law, effective from 17 June 2017, restored many regulations, which had been in force by the end of 2016. The freedom to fell trees and shrubs was restricted.

In the years 2015 and 2017, public administration bodies in Przeworsk commune charged fees to tree felling to legal persons in the total amount of approx. EUR 77 500, which were remitted in full. 
Therefore, in the analysed years 2013-2017, no funds arising from tree and shrub felling were transferred to the commune budget. Despite the high rate of tree felling during the period from 1 January to 17 June 2017, the overall condition of the tree stand in Przeworsk was assessed as good, and no large areas deprived of vegetation were noted in the commune area.

\section{References}

[1] Emerson H.J., Gillmor D.A. The rural environment protection scheme of the Republic of Ireland. Land Use Policy, Vol. 16(4), 1999, pp. 235-245. DOI: 10.1016/S0264-8377(99)00018-6

[2] Frank D.J., Hironaka A., Schofer E. The nation-state and the natural environment over the twentieth century. American Sociological Review, Vol. 65(1), 2000, pp. 96-116. DOI: $10.2307 / 2657291$

[3] Król K., Szewczyk B., Pawłowska B. Interactive presentation of environmental issues using Google Fusion Tables on the example of phytosociological images of selected Tenczynek areas. Acta Sci. Pol., Formatio Circumiectus, Vol. 15(4), 2016, pp. 253-264. DOI: 10.15576/ASP.FC/2016.15.4.253

[4] Pollock L.J., Thuiller W., Jetz W. Large conservation gains possible for global biodiversity facets. Nature, No. 546, 2017, pp. 141-144. DOI: 10.1038/nature22368

[5] Green O.O., Garmestani A.S., Allen C.R., Gunderson L.H., Ruhl J.B., Arnold C.A. et al. Barriers and bridges to the integration of social-ecological resilience and law. Frontiers in Ecology and the Environment, Vol. 13(6), 2015, pp. 332-337. DOI: 10.1890/140294

[6] Costanza R., de Groot R., Braat L., Kubiszewski I., Fioramonti L., Sutton P. et al. Twenty years of ecosystem services: How far have we come and how far do we still need to go?. Ecosystem Services, No. 28, 2017, pp. 1-16. DOI: 10.1016/j.ecoser.2017.09.008

[7] Gschwantner T., Schadauer K., Vidal C., Lanz A., Tomppo E., Di Cosmo L., Robert N., Duursma D.E., Lawrence M. Common tree definitions for national forest inventories in Europe. Silva Fennica, Vol. 43(2), 2009, pp. 303-321. DOI: 10.14214/sf.463

[8] Kirkpatrick J.B., Davison A., Daniels G.D. Sinners, scapegoats or fashion victims? Understanding the deaths of trees in the green city. Geoforum, Vol. 48, 2013, pp. 165-176.

[9] Bennett A.C., McDowell N.G., Allen C.D., Anderson-Teixeira K.J. Larger trees suffer most during drought in forests worldwide. Nature Plants, Vol. 1(10), 2015, No. 15139.

[10] Act of 23 April 1964 The Civil Code (Journal of Laws of 2017, item 459).

[11]Burns T.J., Kick E.L., Davis B.L. Theorizing and rethinking linkages between the natural environment and the modern world-system: Deforestation in the late 20th century. Journal of World-Systems Research, Vol. 9(2), 2015, pp. 357-390. DOI: 10.5195/jwsr.2003.237

[12]Ran J., Nedovic-Budic Z. Integrating spatial planning and flood risk management: A new conceptual framework for the spatially integrated policy infrastructure. Computers, Environment and Urban Systems, No. 57, 2016, pp. 68-79. DOI: 10.1016/j.compenvurbsys.2016.01.008

[13] Act of 16 April 2004 on nature conservation (Journal of Laws of 2016, item 2134).

[14]Grecki W., Grzywacz M., Okoń M., Piecha J. Wycinka drzew i krzewów. Procedura administracyjna [Felling trees and shrubs. The administrative procedure]. C.H. Beck, Warszawa, 2017.

[15] Schmieda A., Pillmann W. Tree protection legislation in European cities. Urban Forestry \& Urban Greening, Vol. 2(2), 2003, pp. 115-124. DOI: 10.1078/1618-8667-00028

[16] Kronenberg J. Barriers to preserving urban trees and ways of overcoming them. Sustainable Development Applications, No. 3, 2012, pp. 31-49. 